JOANNA ZARĘBSKA

MONIKA MICHALSKA

\title{
Ecological innovations as \\ a chance for sustainable \\ development - directions \\ and obstacles in their implementation
}

Joanna Zarębska, Ph.D. Eng. University of Zielona Góra, Faculty of Economics and Management Monika Michalska, Ph.D. Eng. University of Zielona Góra, Faculty of Economics and Management

\section{Introduction}

In the document "Strategy Europe 2020", the European Commission defines three priorities, these are (Europe 2020 ..., 2010, p. 3):

- smart growth: developing an economy based on knowledge and innovation,

- sustainable growth: promoting a more resource-efficient, ecologically-friendly and competitive economy,

- inclusive growth: promoting a highemployment economy that provides social and territorial cohesion.

One of the elements of sustainable development comprises ecological innovations (eco-innovations). Ecological innovations are defined in the documents of the European Union as a form of innovation aimed achieving a significant and tangible progress within sustainable development by reducing the impact on the environment or implementing more efficient and responsible management of natural resources, including energy. "Eco-innovations are closely related to the way we use natural resources, to our production and consumption, as well as to the concepts of eco-efficiency and ecological 
industry. They facilitate the transition of production companies from end-ofpipe technologies to closed-loop solutions that minimize the use of materials and energy by changing products and production methods, thus bringing about the competitive edge to many companies and sectors" (Komisja Europejska 2012, pp. 1-2).

Eco-innovation is a relatively new kind of innovation specified in the national literature. The first comprehensive study on the subject was developed by the Polish Central Statistical Office (GUS) in 2006, although individual studies on the implementation of eco-innovations in companies in different regions were being conducted by numerous research centers much earlier (worldwide, they date back to the end of the 1970s). In the literature, eco-innovations are described within the following contexts (Działalność innowacyjna przedsiębiorstw... 2010-2015; Kaźmierczak-Piwko 2012; Potencjał małych... 2008; Wzorce zrównoważonej ... 2011; Zarębska 2008, pp. 73-98):

- reducing material consumption and water consumption per product unit,

- reducing energy consumption and carbon dioxide emissions,

- reducing the pollution of air, water, soil an noise levels,

- facilitating the re-use (recycling) of products after use,

- extending product longevity by increasing stability and strength,

- reducing the use of energy extracted from fossil fuels in favor of renewable energy sources.

This article aims to systematize the concept of ecological innovations and briefly to describe the distribution of eco-innovations from the following standpoints: their implementation in companies (improvement of organizational methods, management, production processes, products and marketing strategies), professional development (green jobs), consumer attitudes, financing methods. What is more, one of the goals is to mark the directions of implementing ecoinnovations in Polish companies in 2006-2014. The analysis of reports from the extensive research studies conducted by GUS, the Polish Agency for Enterprise Development (PARP) and the EU allowed the authors to identify the main opportunities and obstacles in implementing ecological innovations within national companies.

\section{Types of eco-innovations - basic terminology}

Due to the large scope of their meanings, ecological innovations can be interpreted very broadly, and there are therefore many definitions of this term. Carley and Spapens (2000) understand the concept of ecological innovations (eco- 
innovations) as "intentional conduct characterized by initiative, comprising the stage of product design and integrated management during its life cycle, which subsequently contributes to pro-ecological modernization of the industrial era's societies, by accounting for environmental issues in the development of products and related processes. Eco-innovations lead to integrated solutions aimed at reducing the expenditure of resources and energy, while simultaneously improving the quality of products and services. Technological innovation is one of the ways of pursuing eco-innovation" (Carley, Spapens 2000, p. 157).

The Polish Agency for Enterprise Development (PARP) defines ecological innovations as "any innovation, implemented in accordance with the applicable law, which benefits the natural environment, in particular through minimizing consumption of natural resources per produced product unit, as well as minimizing the emission of hazardous substances into the environment during production, use and after use of the product". These innovations may be of the following nature: process, product, organizational or marketing - figure 1 (Woźniak, Strojny, Wojnicka 2010, p. 9).

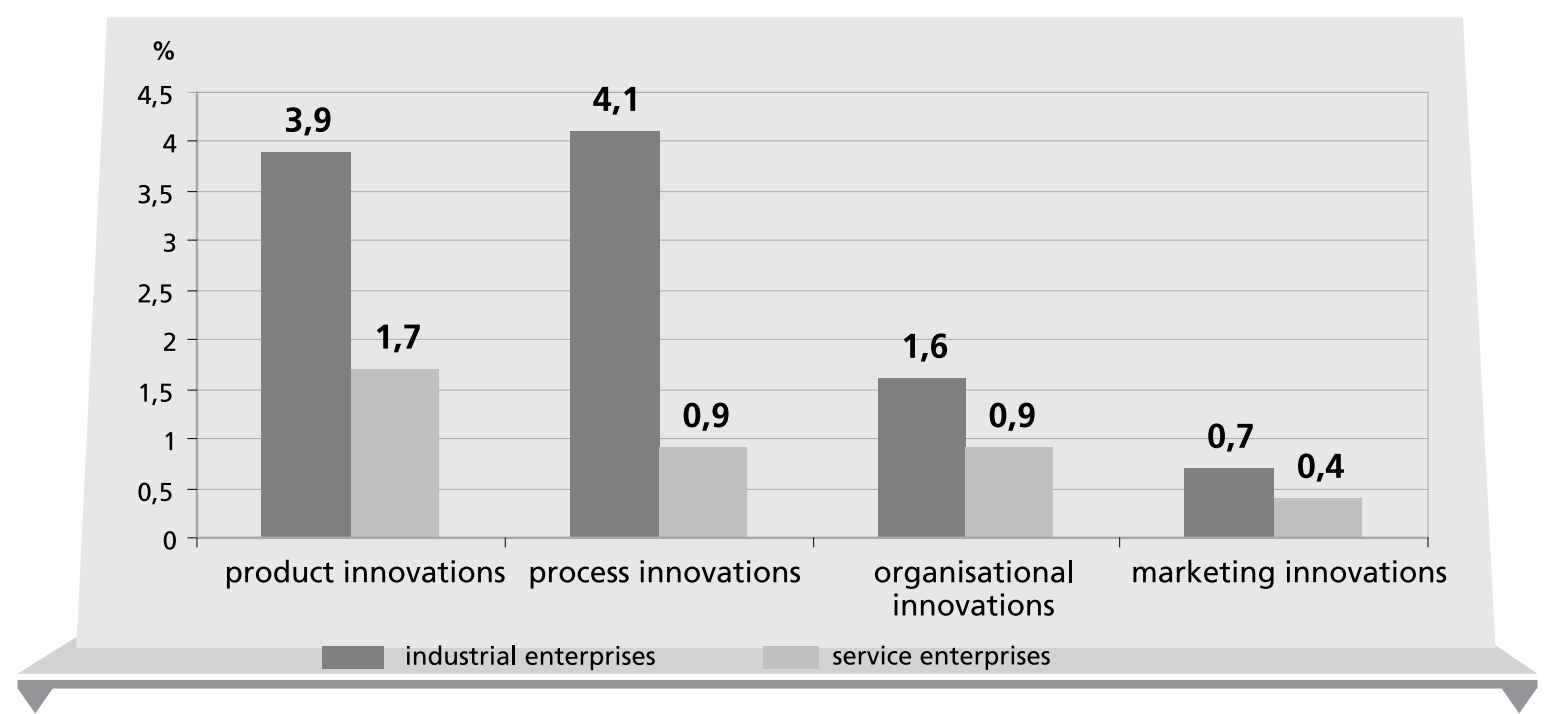

Figure 1. Companies that have introduced eco-innovations as part of different types of innovations implemented, value expressed in \% of companies in total (2012-2014)

Source: Działalność innowacyjna przedsiębiorstw... 2015, p. 125

According to GUS (Działalność innowacyjna przedsiębiorstw... 2015, p. 123), ecoinnovations are „innovations that benefit the environment; a new or significantly 
improved product (or service); a process, an organizational marketing method, that benefit the environment as compared with alternative solutions:

- environmental benefits may be innovation's primary objective or the result of other objectives,

- environmental benefits may develop during the production of goods or services, or during the use of the purchased product or service by end users (individuals, other businesses, institutions, etc.)".

GUS defines process innovations (Działalność innowacyjna przedsiębiorstw... 2015, p. 42) as implementation of „new or significantly improved methods of production, distribution and support of activities concerning products and services. Process innovations include new or significantly improved methods of development and provision of services. Other process innovations include new or significantly improved techniques, equipment and software in auxiliary activities, such as supply, accounting, IT support and maintenance".

Product innovations involve launching "a product or a service that is new or significantly improved with respect to its characteristics or applications. Product innovations in services are based on the introduction of significant improvements within service performance, adding new features or characteristics to existing services or by introducing completely new services". Similarly, A. Chodyński (2003, pp. 95) defines product eco-innovations as "innovations integrating ecological features of products and technology during its entire life cycle (i.e. "from cradle to grave"), thus making them stand out against competition. The goal is to implement the environmental quality objectives".

Organizational innovations involve "implementation of a new organizational method within the business practices adopted by the company (including knowledge management), workplace organization or external relations that have not yet been tested in the enterprise. Organizational innovations should be the result of strategic decisions made by the management. They do not include instances such as mergers and acquisitions, even if it is the first time these have taken place" (Działalność innowacyjna przedsiębiorstw... 2013, p. 47). Of particular importance in this respect are modern tools and instruments for environmental management, implemented more commonly in national institutions. A. Matuszak-Flejszman (2015, p. 73) considers the following to be particularly important:

- environmental management systems (in accordance with ISO 14000, EMAS, Responsible\&Care programs),

- tools for conducting environmental review,

- environmental impact assessment (EIA), 
- life cycle assessment (LCA),

- ecological balance (eco-balance),

- environmental assessment of sites and organizations (EASO),

- environmental auditing,

- methods of multiple decision-making,

- methods of modeling and simulation,

- heuristic methods.

Marketing innovations, meanwhile, involve „implementation of a new marketing concept or strategy that differs significantly from the marketing methods so far pursued within the company. Marketing innovations include significant changes in the product project/product design, packaging, product distribution, product promotion and price formation. They do not include seasonal, regular and other routine changes concerning marketing methods. The aim of marketing innovations is to better meet the needs of customers, open new market outlets or introduce company's new product positioning on the market in order to increase sales". The examples of marketing eco-innovations are (Działalność innowacyjna przedsiębiorstw... 2013, p. 53):

- significant changes in the project/design/packaging of products or services which improve their relationship with the environment (eco-design, LCA),

- new means and techniques of product promotion, such as innovative use of a new advertising medium, environmentally friendly image, introduction of loyalty cards for the so-called. "green clients",

- new methods of product distribution or sales channeling, such as introduction of a franchise or license system for distribution of organic products, direct sales, exclusive retailing, new concepts for product exposure with an emphasis on environmental aspects and relationship of products with the environment,

- new methods of pricing products and services, such as innovative application of new methods of product price adjustment depending on demand, system of discounts for environmentally friendly products and services.

\section{Ecological innovations - research results}

The analysis of the data in GUS, PARP, EU and the Division of Environment and Public Sector Economy Management of University of Zielona Góra was the basis of the authors' assessment of directions and obstacles in implementing ecoinnovations in Poland. The survey results (GUS, PARP, UE) in 2006-2014 and the Cathedral in 2001-2008 involve industrial companies and services.

The research conducted by PARP, "The potential of small and medium-sized 
enterprises in developing new innovative products - environmentally-friendly solutions", (in Polish: "Potencjat małych $i$ średnich przedsiębiorstw $w$ dziedzinie kreowania nowych produktów innowacyjnych - rozwiązania proekologiczne") showed that the most important factor in stimulating entrepreneurs to turn to ecological innovations is legal requirements, as well as expected changes in legislation (Potencjat matych ... 2008, p. 5). In 2006, only less than $1 \%$ of companies indicated "novel, innovative nature of products and services," pointing to the "product prices" as the determining factor (33\% of the companies). Similar research was conducted in 2010 by the Polish Environmental Partnership Foundation (Szpor, Śniegocki 2012, p. 11), showing that about 74\% of companies decide to invest in eco-innovations mainly with mind in subsequent general lowering of production costs, followed by the desire to improve their corporate image $(55 \%)$ and improve their relationship with the environment (55\%).

The studies on eco-innovation were conducted in the Division of Environment and Public Sector Economy Management, at the University of Zielona Góra, as part of the project entitled "Improvement of region's innovation as a result of developing and disseminating good practices related to strategic environmental management in the organizations of Lubuskie Province” (in Polish "Wzrost innowacyjności regionu jako efekt rozwijania $i$ upowszechniania dobrych praktyk $z$ zakresu strategicznego zarządzania środowiskowego w organizacjach województwa lubuskiego"), which were financed from the European Social Fund and state budget within the IROP (Priority II, Measure 2.6). The research comprised a group of 216 participants from across Lubuskie Province. It found that the most effective factors affecting the eco-innovation rate were management systems, namely ISO 14000 and ISO 9000. Those enterprises that implemented ISO 14000 declared a 100\%-sure introduction of eco-innovations. As a result, the companies benefited in the form of reductions in material consumption, energy consumption of processes and the amount of applicable environmental charges. Among the companies following ISO 9000 (quality management system), merely $80 \%$ declared reduction in material consumption, while $78 \%$ claimed to have reduced energy consumption. Out of the organizations that implemented an integrated management system (e.g. both ISO 9000 and ISO 14000, or more), $92 \%$ declared reduction of material and energy consumption, with $77 \%$ having reduced the amount of environmental charges. Analysis of the research results leads to the conclusion that introduction of management systems (in particular ISO 14000) within the company contributes to the implementation of new solutions, ideas and inventions that benefit the environment, also bringing the company tangible economic advantages, such as material and energy savings 
or lower environmental charges (Zarębska 2008, pp. 73-98; Graczyk 2010, p. 12; Kaźmierczak-Piwko 2012, p. 539).

The first GUS study conducted in Poland in 2006-2008, aimed at determining the level of innovation (including environmental innovation), indicated that eco-innovations were introduced by a total of only $26.2 \%$ of industrial enterprises and $15.5 \%$ of companies in the service sector (this applied to innovations benefiting the environment during both production and use). Ecoinnovations during the production stage were opted for by $24.1 \%$ of industrial enterprises and $12.7 \%$ of those in the service sector. In the meantime, ecoinnovations during use were seen among $17.5 \%$ of industrial enterprises and $11.3 \%$ of service companies (Działalność innowacyjna przedsiębiorstw... 2009, p. 7). The innovation index - described as "participation, in the studied sample, of industrial enterprises of a given sector that, within the period of 3 years, introduced innovations" was 20.4\% for companies in Poland in 2009 (the average for the EU-27 was 33.7\%) and remained at a similar level for the following few years (Wzorce zrównoważonej... 2011, p. 11). During this period, investment in innovations (including ecological ones) per company slightly decreased from 809,000 EUR in 2008 to 785,000 EUR in 2010, only to increase again in 2012 to 1 million EUR (the average for the EU-27 in 2012 was 1.15 million). After that, they fell once again for two consecutive years of 2013 and 2014. This fluctuation trend has been observed both in expenditure on investments, as well as in a number of companies qualifying as innovative (Innowacyjność 2010; Innowacyjna przedsiębiorczość ... 2015).

As indicated by the GUS research conducted in the following years 2009-2014, most eco-innovations were introduced in large companies employing 250 or more people, and these were in majority production companies (service companies to a lesser extent) regardless of the category and type of innovation. Figure 2 contains a summary of participation of those companies that have introduced eco-innovations benefiting the environment in the_production phase of goods or services in the years 2006-2008 and 2012-2014. Figure 3, meanwhile, shows the same summary for the use phase of goods and services by end users. There is no available GUS research involving implemented eco-innovations in 2009-2011. It has contributed to the time gap visible in figure 2 and 3.

In 2012-2014 (figure 2), the most cited environmental benefit achieved by industrial companies was "re-use of waste, water or materials for own use or sale" $(8.0 \%)$, while among service companies it was "reduction of energy consumption or carbon footprint" (4.6\%). As compared to 2006-2008, in 20122014 there was a significant decrease in the percentage of production companies 
which indicated benefits in all categories, e.g. the biggest drop was recorded in the category of "reduction of energy extracted from fossil fuels in favor of renewable energy sources", which fell from 13.8\% 2006-2008 to 2.3\% in 2012-2014. As far as service companies are concerned, the differences are not that big with respect to particular categories of benefits, and in the category of "reduction of energy consumption per production unit" there was even an increase in the number of companies that pointed to this environmental benefit in 2012-2014 (from $3.4 \%$ to $4,6 \%$ ).

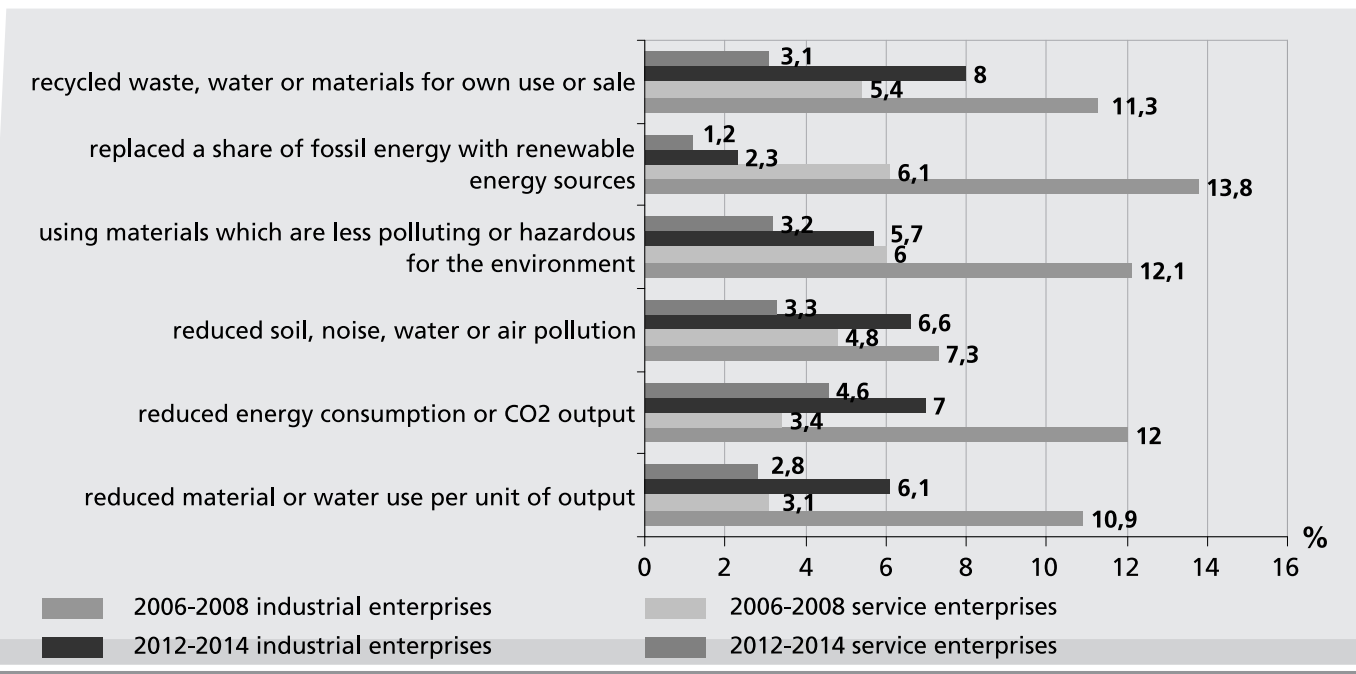

Figure 2. The percentage of companies that have introduced innovations benefiting the environment in the production phase of goods or services, in 2006-2008 and 2012-2014

Source: own study based on: Działalność innowacyjna przedsiębiorstw... 2010-2015; Innowacyjna przedsiębiorczość ... 2015, pp.1-7; Potencjał innowacyjności... 2015

The category "reduction of energy consumption and carbon dioxide emissions" (fig. 3) was the most frequently indicated example of the environmental benefits achieved during the use of a purchased product or service by end users, both in industrial and service companies (respectively, 5.9\% and 4.8\% in 2012-2014, and $10.9 \%$ and $6.8 \%$ in 2006-2008). Worth noting is the category "reduction of the pollution of air, water, soil, noise," which in $2006-2008$ was cited by $12 \%$ of industrial enterprises, and by 5.7\% in 2012-2014 (respectively 7.2\% and 3.8\% for service companies). 


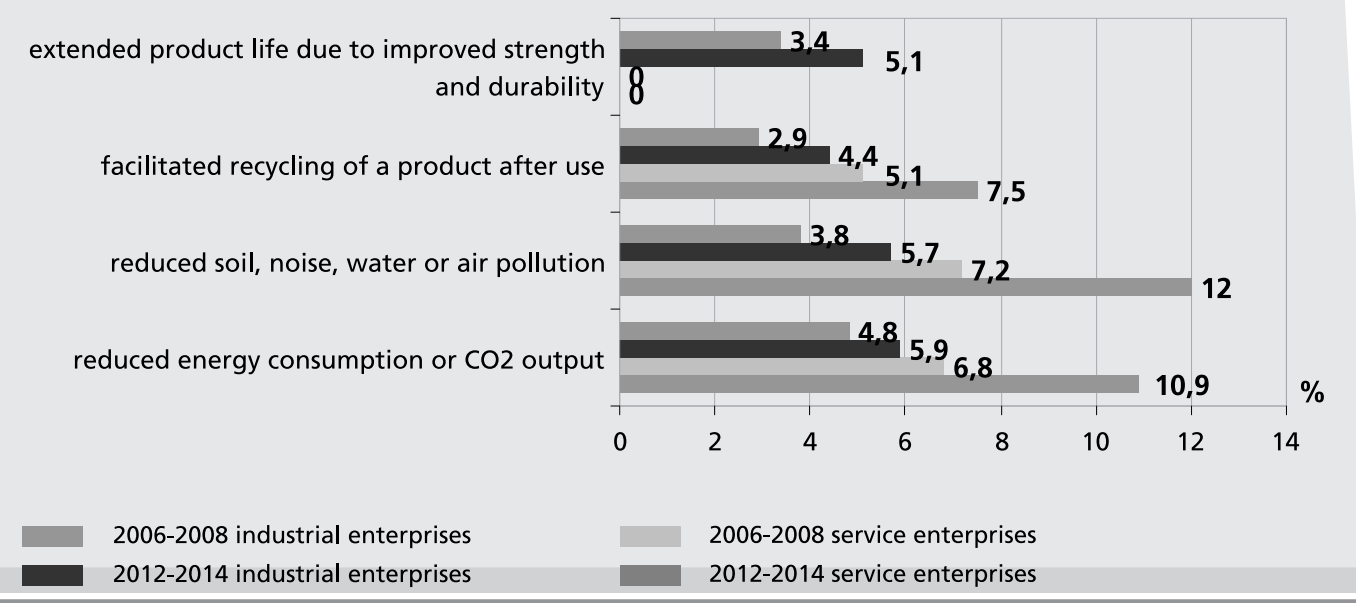

Figure The percentage of companies that have introduced innovations benefiting the environment in the use phase of goods and services by end users according to the types of benefits, in 2006-2008 and 2012-2014

Source: own study based on: Działalność innowacyjna przedsiębiorstw... 2010-2015; Innowacyjna przedsiębiorczość ... 2015, pp. 1-7; Potencjał innowacyjności... 2015

These innovations were made possible thanks to the emergence of global market demand for the so-called "green jobs" (sometimes called "green collar jobs"). A. Lewandowska and Z. Foltynowicz (2015, pp. 9-14) state that those jobs are a great opportunity for professional development and sustainable economic growth, as well as country's own development accompanied by simultaneous prevention of environmental degradation, biodiversity loss and unsustainable use of natural resources. According to documents of the European Union, "green jobs are any kind of professional activity that helps protect the environment and fight climate change by saving energy and raw materials, promoting the use of renewable energy, reducing waste and pollution, and protecting biodiversity and ecosystems. Developing sustainable consumption and production patterns creates new jobs and transforms those existing into highquality green jobs, not only across virtually all sectors, but also along the entire value chain, from research to production, distribution and services in: new sectors of advanced technologies, such as renewable energy sector; in traditional sectors, such as production and construction; in agriculture and fishing; and in service sectors, such as gastronomy, tourism, transportation and education " (Zielone ... 2014, p. 6). 


\section{Eco-innovations - determinants of implementation}

The Polish Agency for Enterprise Development indicates four main factors affecting the rate of implementation of eco-innovations (Potencjat innowacyjności ... 2015, p. 10; Wzorce zrównoważonej... 2011):

- supply factors - related to technological trends (e.g. CP, CSR),

- demand factors - related to consumer preferences in terms of environmentallyfriendly production methods or products (greens consumers),

- regulatory environment (legislation),

- company-specific factors - related to industry, company size, environmental policy, financial strength, market share.

An important factor influencing the implementation rate and type of ecoinnovations is the interest of companies and consumer in environmental protection (supply and demand), especially in tools and strategies for environmental management. In this regard, important are the following aspects: eco-design, eco-labeling, implemented environmental management standards, such as EMAS, ISO 14000, or strategies such as CP (Clean Production) CSR (Corporate Social Responsibility). These tools prove effective since they indirectly highlight environmentally-friendly products and production methods, as well as companies. Apart from that, they also support ecologically conscious consumers (i.e. green consumers) in their market decisions. In this case, individual preferences and patterns of behavior are equally important as the social, economic and political environment, as well as technological capabilities. Unfortunately, M. Koszewska's research shows that consumers on the Polish market have trouble finding and distinguishing ecological products from conventional ones, and they have a lack of confidence in eco-labels and other ISO standards. At the same time, they exhibit high sensitivity at the level of declarations and moderate environmental awareness. With that being said, however, the author of the study sees great opportunities for the development of eco-innovations and the so-called driver user innovations in the precise diagnosis of the preferences of "green consumers" and market outlets for eco-innovative products (Koszewska 2015, pp. 15-21).

In the literature, the most frequently mentioned environmental benefits resulting from the implementation of eco-innovations are (EUROPE 2020.. 2010; Potencjał innowacyjności ... 2015; Wzorce zrównoważonej... 2011 ):

- reduction of material consumption and water consumption per product unit,

- reduction of energy consumption and carbon dioxide emissions,

- reduction of the pollution of soil, water, air or noise, 
- use of materials less polluting and less hazardous for the environment,

- reduction of the use of energy extracted from fossil fuels in favor of renewable energy sources,

- re-use (recycling) of waste, water and materials for own use or sale.

Industrial companies most frequently mention the benefit of reuse of waste, water and materials for own use or sale, while service companies tend to point to reduction of energy consumption and carbon dioxide emissions.

Legal regulations are also of significant important in the literature. There is a negative correlation between the number of legal regulations and the propensity for innovation. Legal regulations are most often a barrier inhibiting the introduction of eco-innovations by entrepreneurs.

Company-specific factors comprise a group of internal (endogenous) and external (exogenous) factors. The internal factors include all factors related to enterprise management system, namely: environmental policy business competition strategy, environmental awareness of personnel and often also their qualifications (lack of specialists is a major barrier), aspirations of managers, voluntary commitments, financial strength. Among the external factors determining obstacles and opportunities for the implementation of ecoinnovations are environment-related changes such as: scientific and technological achievements, economic and social progress, as well as other factors including but not limited to: competition, market share, consumer expectations, legal regulations concerning environmental protection.

The main barrier to the implementation of eco-innovations and taking proenvironmental actions (including use of technology providers or environmental services) among Polish companies is the need to engage their own financial resources. There is a variety of funding sources for eco-investments on the market, and these are: own funds, funds of related entities (subsidiaries or affiliates), funds of the financial sector entities (bank loans, VC - venture capital), funds of other companies (from outside of the financial sector), public funds, funds of international organizations. In Poland, the Ministry of Environment considers the following sources to be fundamental in financing environmental investments: National Fund for Environmental Protection and Water Management (in Polish: NFOŚiGW - Narodowy Fundusz Ochrony Środowiska i Gospodarki Wodnej) (and subordinate regional funds), own funds of enterprises, municipalities and budgetary units, national banks, state budget and regional budgets, foreign financial resources (including EU grants), and others (e.g.: ARMA - Agency for Restructuring and Modernization of Agriculture, Rural Development Foundation, EcoFund) - see table 1. 
Table 1. Sources of financing ecological innovations in Poland

\begin{tabular}{|c|c|}
\hline Type of funds & Financial support mechanism \\
\hline EU funds & $\begin{array}{l}\text { - Strategy „Europe 2020” (initiatives such as „Union of innovations”, „Resource- } \\
\text { efficient Europe”), } \\
\text { - Programme "Horizon 2020”, } \\
\text { - Programme LIFE (via NFOŚiGW), } \\
\text { - Programme INTERREG Europe 2014-2020, } \\
\text { - Central Europe Cooperation Program for 2020, } \\
\text { - POIiŚ - Operational Programme Infrastructure and Environment, } \\
\text { - POIG - Operational Programme Innovative Economy, }\end{array}$ \\
\hline State funds & $\begin{array}{l}\text { - Programme GEKON - Ecological Concepts Generator ( joint program of } \\
\text { - InFOSiGW and NCBiR), } \\
\text { - Initiative EUREKA (NCBiR), } \\
\text { - NFOŚiGW - National Fund for Environmental Protection and Water } \\
\text { - Management, } \\
\text { - NCBiR - National Centre for Research and Development; }\end{array}$ \\
\hline $\begin{array}{l}\text { Funds of } \\
\text { financial sector } \\
\text { entitites }\end{array}$ & $\begin{array}{l}\text { - Bank loans, e.g. BOŚ within "Energia na Plus”, BGK within „Kredyt na } \\
\text { innowacje technologiczne”, } \\
\text { - Loans granted by the Environemtal Proection Fund (e.g. „Bocian”), }\end{array}$ \\
\hline Venture capital & $\begin{array}{l}\text { - PE/VC (Private Equity/Venture Capital), } \\
\text { - Public-private mechanism with the use of capital funds, e.g. BRIdge Alfa. }\end{array}$ \\
\hline
\end{tabular}

Source: own study based on: Europe 2020... 2010; Ekoinnowacje, klucz ... 2012; Szpor, Śniegocki 2012, pp. 14-17; Informacja o realizacji strategii ... 2015, pp. 32-44

According to the Environmental Partnership Foundation research, more than $68 \%$ of companies indicate lack of financial resources as the main reason for not implementing eco-innovations. Another barrier for enterprises is "too high implementation costs" (61\%), followed by: difficulty in finding partners (21\%), risk aversion associated with implementation of new technologies (15\%), problems in establishing relationships with the R\&D community $(10 \%)$, lack of access to information regarding new eco-innovative technologies (6\%) (Szpor, Śniegocki 2012, p. 11). At the same time, approximately $9 \%$ of companies consider "government grants, subsidies or other financial incentives to introduce environmentally beneficial innovations" as unimportant in deciding about their implementation. An equally important barrier is the fact that "almost two in three researched companies are unaware of the possibilities of financing innovative 
pro-environmental actions from the EU funds" (Potencjat matych... 2008, p. 116). This lack of awareness results in the need for financing eco-innovation from own funds (which, in most cases, is affordable for large companies) or from national resources and those of the financial sector (which, according to the research, is not a big motivation for their implementation).

\section{Conclusion}

The analysis of national documents and those of the European Commission leads to the conclusion that, although Poland is one of the least eco-innovative countries in Europe, it has a large potential for development in that area. The factors influencing the decision by Polish companies to implement ecoinnovations are: legal regulations concerning the environment, applicable taxes, fees and penalties associated with environmental pollution, desire to reduce high costs of energy, water and materials, current or expected market demand for eco-innovations, improving corporate image, promoting good environmental practices among companies, demand for eco-innovative products, need to meet requirements for contracts in public procurement.

The implemented ecological innovations represent a great opportunity for sustainable development of our country, consistent with the commitments and regulations of the European Union. Increasing the eco-innovation index is a priority for Polish companies which, unfortunately, still face more obstacles than incentives in this regard, while opportunities that arise are not always properly taken advantage of (due to lack of knowledge, awareness, skills, or ignoring needs).

\section{Abstract}

Ecological innovations as a chance for sustainable development - directions and obstacles in their implementation

Ecological innovations (eco-innovations) can be considered from the standpoint of innovations implemented within the company in order to: improve organizational and management methods, production process, products, marketing, external relations with the environment and society. They are also a chance for professional development (the so-called green jobs) or can be viewed in terms of consumer interest. Consumer interest in ecoinnovations, and subsequently growth in sales of products and services, influence the effectiveness of innovations and worthiness 
of their further funding. Eco-innovations, however, are not limited only to the company and the services, but also the quality of life and environment protection, inevitably followed by the present and future sustainable development. In the paper all the above has been presented with GUS, PARP, UE and the Division of Environment and Public Sector Economy Management (University of Zielona Góra) studies. The research involved eco-innovations in companies and indicated the directions and obstacles of their implementation in Poland.

Keywords: sustainable development, eco-innovative products (ecologically innovative products), green jobs, environmental management.

\section{Streszczenie}

Innowacje ekologiczne szansą dla zrównoważonego rozwoju kierunki i przeszkody implementacji

Innowacje ekologiczne (ekoinnowacje) można rozpatrywać $\mathrm{z}$ punktu widzenia innowacji wdrażanych w przedsiębiorstwie w celu: ulepszenia metod organizacji i zarządzania, produkcji, produktu, marketingu, relacji zewnętrznych ze środowiskiem i społeczeństwem, jak również jako szansa rozwoju zawodowego - tzw. zielonych miejsc pracy, czy pod względem zainteresowania konsumentów. Od zainteresowania konsumentów ekoinnowacjami, a w rezultacie od wzrostu sprzedaży produktów i usług, zależy efektywność innowacji i ich dalszy sens finansowania. Ekoinnowacje to jednak nie tylko przedsiębiorstwo i usługi, to również komfort życia i ochrona środowiska, a co za tym się kryje, również obecny i przyszły zrównoważony rozwój. W artykule omówiono powyższe zagadnienia prezentując wyniki badań GUS, PARP, UE i Katedry ZŚiGP Uniwersytetu Zielonogórskiego dotyczące ekoinnowacji przedsiębiorstw oraz wskazano kierunki i przeszkody ich implementacji w warunkach Polski.

\section{Słowa}

kluczowe: zrównoważony rozwój, ekoinnowacyjne produkty, zielone miejsca pracy, zarządzanie środowiskowe. 


\section{References}

1. Carley M., Spapens P. (2000), Dzielenie się światem, Instytut na rzecz Ekorozwoju, Białystok-Warszawa.

2. Chodyński A. (2003), Innowacyjność i jakość w strategii rozwoju firmy. Zarzadzanie produktowymi innowacjami ekologicznymi, Wyd. Wyższej Szkoły Zarządzania i Marketingu w Sosnowcu, Sosnowiec.

3. Działalność innowacyjna przedsiębiorstw w latach 2006-2009 (2010), Główny Urząd Statystyczny, Urząd Statystyczny w Szczecinie, Informacje i opracowania statystyczne, Warszawa.

4. Działalność innowacyjna przedsiębiorstw w latach 2008-2010 (2012), Główny Urząd Statystyczny, Urząd Statystyczny w Szczecinie, Informacje i opracowania statystyczne, Warszawa.

5. Działalność innowacyjna przedsiębiorstw w latach 2010-2012 (2013), Główny Urząd Statystyczny, Urząd Statystyczny w Szczecinie, Informacje i opracowania statystyczne, Warszawa.

6. Działalność innowacyjna przedsiębiorstw w latach 2012-2014 (2015), Główny Urząd Statystyczny, Urząd Statystyczny w Szczecinie, Informacje i opracowania statystyczne, Warszawa.

7. Ekoinnowacje, klucz do przyszłej konkurencyjności Europy, (2012), Komisja Europejska http://ec.europa.eu/environment/pubs/pdf/factsheets/ ecoinnovation/pl.pdf (09.01.2016 - access date).

8. Europe 2020. A strategy for smart, sustainable and inclusive growth (2010), Communication from the Commission, $\operatorname{COM}(2010), 2020$ final, European Commission, Brussels, 3.3.2010.

9. Graczyk M. (2010), Technologie środowiskowe jako wyznacznik ekoinnowacji, „Ekonomika i Organizacja Przedsiębiorstwa” nr 4, s. [12].

10. Informacja o realizacji strategii innowacyjności i efektywności gospodarki w roku 2014 (2015), Ministerstwo Gospodarki, Warszawa.

11. Innowacyjność 2010 (2010), Polska Agencja Rozwoju Przedsiębiorczości, Warszawa, http:// badania.parp.gov.pl/files/74/81/380/10838.pdf (09.01.2016 - access date).

12. Innowacyjna przedsiębiorczość w Polsce. Odkryty i ukryty potencjał polskiej innowacyjności (2015), Polska Agencja Rozwoju Przedsiębiorczości, Warszawa, http://www.parp.gov.pl/files/74/81/806/22523.pdf (09.01.2016 - access date).

13. Kaźmierczak-Piwko L. (2012), Determinanty działalności ekoinnowacyjnej przedsiębiorstw, "Zarządzanie i Finanse", vol. 10, no 1, part 2.

14. Koszewska M. (2015), Czy Polscy konsumenci saprzygotowani naekoinnowacje? Wyzwania i bariery, [in:] Witczak J. (tech. ed.), EVENT o EKOinnowacjach, conference materials, Uniwersytet Ekonomiczny w Poznaniu, Poznań.

15. Lewandowska A., Foltynowicz Z. (2015), Ekoinnowacje jako szansa rozwoju zawodowego - zielone miejsca pracy, [in:] Witczak J. (tech. ed.), EVENT 
o EKOinnowacjach, conference materials, Uniwersytet Ekonomiczny w Poznaniu, Poznań

16. Matuszak-Flejszman A. (2015), Ekoinnowacyjne narzędzia w zrządzaniu przedsiębiorstwem, [in:] Witczak J. (tech. ed.), EVENT o EKOinnowacjach, conference materials, Uniwersytet Ekonomiczny w Poznaniu, Poznań.

17. Potencjat matych $i$ średnich przedsiębiorstw w dziedzinie kreowania nowych produktów innowacyjnych - rozwiązania proekologiczne (2008), Polska Agencja Rozwoju Przedsiębiorczości, Warszawa.

18. Potencjat innowacyjności $w$ przedsiębiorstwach $i$ otoczeniu spotecznogospodarczym. Dobre przykłady, słabości, perspektywy na przyszłość (2015), Polska Agencja Rozwoju Przedsiębiorczości, Warszawa.

19. Problemy oddziaływania małych i średnich przedsiębiorstw na środowisko (2010), Fundacja Partnerstwo dla Środowiska, Warszawa.

20. Szpor A., Śniegocki A. (2012), Ekoinnowacje w Polsce. Stan obecny, bariery rozwoju, możliwości wsparcia, Instytut Badań Strukturalnych, Warszawa.

21. Woźniak L., Strojny J., Wojnicka E. (2010), Jak budować przewage konkurencyjna dzięki ekoinnowacyjności?, Polska Agencja Rozwoju Przedsiębiorczości, Warszawa.

22. Wzorce zrównoważonej produkcji (WZP) w dziatalności przedsiębiorstw - propozycja rozwiazań systemowych wspierajacych wdrażanie WZP w MSP. Raport z analizy danych zastanych (2011), Polska Agencja Rozwoju Przedsiębiorczości, Warszawa.

23. Zielone miejsca pracy. Sprawdzone rozwiazania dla Europy (2014), Grupa Zielonych/Wolny Sojusz Europejski (Parlament Europejski) oraz Green New Deal, Bruksela - Belgia, http://www.greens-efa.eu/fileadmin/ dam/Documents/Publications/GND/Green_jobs_PL.pdf (09.01.2016 access date).

24. Zarębska J. (2008), Zarządzanie cyklem istnienia wyrobów - dobra praktyka w zakresie wzrostu innowacyjności produktów, [in:] Graczyk M. (ed.), Dobre praktyki prośrodowiskowe jako stymulatory innowacyjności w regionie, Uniwersytet Zielonogórski, Zielona Góra. 